\title{
Top Russian institutes get reduction in power bills
}

\begin{abstract}
Moscow. The Russian government has granted 50 research institutions a reprieve from the crippling electricity bills they have been facing as a result of recent inflation. The government has announced that these institutions will have to pay only half of the money they owe. But another 270 institutes that were originally scheduled for tariff reductions are being left to negotiate discounts individually with local officials of the electricity supply company.

Electricity bills

have increased 15-

fold since the be-

ginning of 1993,

but the science

budget has only

been increased by a

factor of four in the

same period. Some
\end{abstract}

of these bills, issued

by the company

Unified Electric

System, are compa-

rable in size to the

\section{Saltykov: reputation}

is at stake. ment was late in paying the institute's grant, and scientists had to decide beıween turning on the accelerator and getting paid.

But the Joint Institute for Nuclear Research (JINR) in Dubna has not had the choice of turning off the equipment, as it is bound by international agreements. As a result, it is accumulating an enormous debt.

Last November, Vladimir Kadyshevsky, the director of the JINR, asked Yegor Gaidar, then first deputy premier, to resolve the problem (Nature 367, 208; 1994). An agreement was reached with the Ministry of Fuel and Energetics, and was supposed to be signed on 26 December.

Since then, however, the signing of the agreement has been postponed several times, and Gaidar's resignation in December led to speculation that the deal had fallen through. The Ministry of Fuel and Energetics is known to oppose the idea of reduced rates for research institutes, although it did not openly refuse to sign the agreement.

Saltykov's announcement that only half of the electricity bills will have to be paid will help the institutions concerned. But the remaining 270 institutes will have to find some other way to deal with the problem. One solution would be for these institutes to approach officials of the energy agencies directly, rather than using the government as an intermediary. The director of one such institute says they may be given equivalent reductions because local officials often resent central intervention, and are sympathetic to local debtors.

The directors of the institutes that have applied for reduced tariffs are watching the struggle between ministries not only with concern for their institutes but also to see how much influence Saltykov actually holds in the government. Some feel that not only the minister's reputation, but possibly his seat, is at stake.

Vladimir Pokrovsky

\section{Kohl to chair German advisory council}

Munich. As part of its campaign to improve cooperation between the scientific community, German industry and government policy-makers, the German cabinet last week decided to set up an advisory council for research, technology and innovation, to be chaired by the Chancellor, Helmut Kohl.

The council has the strong support of the Ministry of Research and Technology (BMFT), which will provide it with administrative support. In addition to Paul Krüger (CSU), the minister of research, its members will include the minister of education and the economics minister, as well as repre- sentatives from science, industry, trade unions and the government.

The names of those appointed to the council are expected to be announced by the chancellor within the next two weeks, and the council has been asked to address issues of importance to Germany's economy.

Possible themes to be investigated include ways of encouraging the public's acceptance of new technologies, and how to improve the implementation of interministerial decisions, for example by funding personnel exchanges between universities and industry.

\section{Canada drops its plans to build K-meson facility}

Quebec. In its first budget since winning last October's general election, Canada's Liberal government has scuttled the 'Kaon Factory' project, shifted the focus of the country's space programme away from the US space station towards domestic needs, and promised sustained support for its national research councils.

The demise of the Kaon project, designed for the mass production of K-mesons, will follow the withdrawal of C\$236 million (US\$184 million) promised by the former Progressive Conservative government. The controversial project was to have been an extension of TRIUMF (Tri-University Meson Facility) in British Columbia, and was intended to place Canada in the forefront of particle physics research.

It was Kim Campbell, defeated in the polls by Jean Chrétien in her bid for re-election as prime minister, who promised support for the project in 1991 when she was justice minister. At the time, she was the House of Commons representative for the province of British Columbia.

Her announcement drew immediate charges of political favouritism, as her government's own science advisory bodies including the National Advisory Board for Science and Technology which Prime Minister Brian Mulroney chaired - had unanimously recommended against the project.

Janet Halliwell, then chairperson of the Science Council of Canada, said at the time that, given the advisory bodies' recommendation, the government's decision raised a question mark over their role. The Science Council was later dissolved by the Conservative government.

Canada's position on the space station remains uncertain. In a draft of the budget speech distributed to the press, Paul Martin, the finance minister, announced that Canada would "negotiate an orderly withdrawal". But after a direct telephone appeal from President Bill Clinton, he changed this to "an orderly reduction" in commitments to the programme.

The plan is to reduce the amount the previous government had promised, and to add a further $\mathrm{C} \$ 800$ million for a new, longterm Canadian space programme that will emphasize applications perceived to be in Canada's best commercial and job-creating interests, such as remote sensing and telecommunications satellites.

Finally, apparently responding to concern about underfunding of the National Research Council (NRC), the government promised a funding increase for NRC's 1994-95 budget. It has also spared from cuts all the bodies that provide money for university research. 